\title{
Mobilising the potential held by one's entire linguistic repertoire for positive youth development
}

\author{
Janja Žmavc \\ Educational Research Institute, Ljubljana, Slovenia
}

\section{Abstract}

In the article, we discuss the role played by language and multilingualism as relevant contexts for promoting a positive youth development perspective (i.e., PYD). Today, multilingualism is generally seen as individuals' mastering of a complex linguistic repertoire associated with cognitive, social, personal, academic and (expected) professional benefits (Herzog-Punzenberger et al., 2017). Europe's education policies identify multilingualism as one of the main pillars of global and multicultural education. EU institutions therefore encourage the member states to develop new "multilingual and whole-school approaches that equally include the language of schooling, foreign languages and home languages of students across all school subjects, curriculum, as well as involving parents and the wider school community in their learning process" (Staring \& Broughton, 2020, p. 17). In the article, we present contemporary notions of multilingualism that underpin relevant EU recommendations to integrate multilingual approaches in education. We also search for points of intersection that could establish possibilities for conceptualising the language context of PYD with theories of multilingualism and its various dimensions in the school environment (especially those of the language of schooling, first language, foreign languages) with emphasis on students with an immigrant background. ${ }^{1}$

The Slovenian Research Agency supported this article as part of the project Positive Youth Development in Slovenia: Developmental Pathways in the Context of Migration (PYD-SI Model) [J5-1781] that was led by Ana Kozina. 
Keywords: multilingualism, PYD, the language of schooling, language anxiety, migrant education

\section{Spodbujanje posameznikovega celotnega jezikovnega repetoarja kot potencial \\ za pozitivni razvoj mladih \\ Povzetek}

V prispevku raziskujemo vlogo jezika, pri tem zlasti večjezičnosti kot relevantnega konteksta v okviru paradigme pozitivnega razvoja mladih (PYD). Večjezičnost danes $\mathrm{v}$ splošnem razumemo kot posameznikovo obvladovanje kompleksnega jezikovnega repertoarja, ki se tesno povezuje s kognitivnimi, družbenimi, osebnostnimi, pa tudi z učnimi in (pričakovanimi) poklicnimi koristmi (Herzog-Punzenberger et al., 2017). Evropske izobraževalne politike opredeljujejo večjezičnost kot enega glavnih stebrov globalne in multikulturne vzgoje in izobraževanja. Zato ni naključje, da institucije v okviru Evropske unije svoje članice spodbujajo k razvijanju novih "večjezičnih in vsešolskih pristopov, ki kot enakovredne $\mathrm{v}$ učni proces vključujejo učne in tuje jezike, skupaj z jeziki družinskega okolja, ki jih govorijo učenci in dijaki, na ravni vseh učnih predmetov ter kurikula, kot tudi z vključevanjem njihovih staršev in širšega šolskega okolja” (Staring \& Broughton, 2020, p. 17). V prispevku orišemo aktualna sodobna pojmovanja večjezičnosti, na katerih so utemeljena relevantna priporočila Evropske unije za vključevanje večjezičnih pristopov v vzgojo in izobraževanje. $\mathrm{Na}$ tej podlagi v nadaljevanju iščemo možne stične točke, ki bi lahko omogočile konceptualizacijo jezikovnega konteksta v okviru paradigme pozitivnega razvoja mladih s teorijami večjezičnosti in njenih različnih dimenzij v kontekstu šolskega okolja (zlasti učnega, prvega in tujih jezikov) s poudarkom na učencih in dijakih s priseljenskim ozadjem.

Ključne besede: večjezičnost, pozitivni razvoj mladih, učni jezik, jezikovna anksioznost, izobraževanje priseljencev

\section{Introduction}

The article reflects the possibilities of interdisciplinary research combining certain multilingual perspectives from the sociolinguistics field with positive youth development (PYD). This line of research has yet to be considered on its own and in the article we wish to outline the scope of the language context within the PYD model by indicating certain key features of multilingualism and its research while also tackling two fundamental questions along the way: 
1. What can multilingualism, its research, and implementation in education gain by exploring perspectives like PYD?

2. Which topics, issues and findings in the field of multilingualism are relevant for shaping models and practical interventions that enable adolescents' strengths to be identified and promoted, ones that would not normally be expected, and thereby change the view often reflected in traditional assumptions on the role held by positive youth development.

Our research forms part of a larger project Positive Youth Development in Slovenia: Developmental Pathways in the Context of Migration (PYD-SI Model), whose principal aim is to investigate the longitudinal pathways for positive youth development. The project focuses on identifying individual and contextual factors that promote positive outcomes on the levels of the individual, school and society able to prevent risky or problem behaviour. By recognising language as one such specific context in the PYD-SI Model, we try to bring attention to the role of multilingualism in both education and in the design of prevention programmes that assist young people to more successfully develop their self-image and become aware of cultural and linguistic diversity while strengthening their role in the community (e.g., home, school). In this process, their plurilingual communication competence also plays an important part, understood here as both a composite competence of an individual's knowledge and experience with different languages and cultures, and a fundamental means of making meaning and establishing relationships with others (Coste et al., 2009, p. 11).

\section{Multilingualism: some conceptualisations and contemporary research}

Multilingualism is a phenomenon as old as humanity. It is also a fundamental concept that has always defined Europe in social, cultural and political terms (Burke, 2004). The global political situation coupled with economic and technological development, which have stimulated global (transnational) mobility in the 21st century, have put multilingualism at the forefront of different political, social and educational contexts (Cenoz, $2013 \mathrm{~b}$, p. 4). These contexts make multilingualism an essential element in the everyday life of individuals, where an individual's mastering of a complex linguistic repertoire is associated with their cognitive, social, personal, 
academic and professional benefits (Herzog-Punzenberger et al., 2017, p. $8){ }^{2}$ Compared to the role of multilingual practices in history, contemporary multilingualism is more visible and valued since it has become a much more global and diverse phenomenon. It is spread across different parts of the world, social classes, professions, and socio-cultural activities (Comanaru \& Dewaele, 2015). Further, due to technological development, multilingualism is no longer limited to oral or written forms of communication and language use but has evolved to become an instantaneous and multimodal practice that routinely takes place over vast distances and, in large part, also in virtual space (Aronin \& Singelton, 2008; Cenoz, 2013b).

\section{Definitions: from multilingualism and plurilingualism to translanguaging}

Contemporary multilingualism is thus necessarily viewed as an interdisciplinary and multidimensional research topic that may be approached from different perspectives and disciplines, such as linguistics, psycholinguistics, sociolinguistics, and education complete with its contexts and research fields like pedagogy, didactics, education policies etc. Consequently, the term has attracted many definitions that have changed through time according to the shift in the trajectory of research of bi- and multilingualism, particularly marked by the normative perspective, and transformed from a monolingual to a bi-/multilingual norm. Moreover, the standard views of multilingualism as a psychologically and socially harmful phenomenon very commonly found in the early days gradually evolved into the contemporary general acknowledgement that multilingualism is a continual, dynamic ability to command two or more languages, which comprises demonstration of certain minimal level of competence in speaking, listening, reading and writing, with a positive social connotation. Namely, the ability to master two or more languages has been recognised as bringing "opportunities not only to the individual but also to the society as a whole" (Wei et al., 2002, p. 3). Correspondingly, several dimensions are stressed in definitions of multilingualism, such as the individual and social dimension of multilanguage use, the question of language proficiency

2 Here, we have in mind Gumperz's concept of repertoire (1964), which also gave rise to the notion of a plurilingual repertoire within ECML research, which is summarised as the »totality of linguistic, sociolinguistic, metalinguistic and (socio)cultural knowledge related to several languages (and their varieties and registers), mastered at different degrees and for different use, that is available to an individual in an (exolinguistic) communicative and interactive situation« (Chen \& Helot, 2018, p. 170). 
in the multilingual context, and the role of the number of languages (two or more) in use in society or by the individual (e.g., Cenoz, 2013b; Dewaele, 2016; Kemp, 2009). For example, a social situation is foregrounded in societal multilingualism, which "conveys the ability of societies, institutions, groups, and individuals to have regular use of more than one language in their everyday lives over space and time" (Franceschini, 2011, p. 346). On the other hand, in individual multilingualism, a person's ability to use two or more languages in different communicative situations with various degrees of competence is emphasised (Cenoz, 2013b, p. 5). The social and individual dimensions cannot be neatly separated. While observing multilingual practices, other subdimensions can also be distinguished, such as additive and subtractive multilingualism (Lambert, 1974) where the individual's linguistic repertoire is connected to the social context and refers to the formal interventions of languages added or subtracted from a person's repertoire due to the specifics of the education system or immigration.

Within the (European) social context, it is essential to mention the European Commission's education agenda where multilingualism is seen as a critical pillar of education that enables better integration into Europe's social, learning and professional processes. Further, in the context of language learning the multilingual perspective shows the importance of valuing linguistic diversity as one of the constitutive notions of Europe and as a result of the recent migration processes and increased within-EU mobility (2019). The European Commission and the Council of Europe are the two central European institutions when it comes to issuing education policies. With resolutions and policy guides, they encourage their member states to develop new "multilingual and whole-school approaches that equally include the language of schooling, foreign languages and home languages of students across all school subjects' curriculum, as well as involving parents and the wider school community in their learning process" (Staring \& Broughton, 2020, p. 17). In the Council of Europe's Guide for developing and implementing plurilingual and intercultural education (Beacco et al., 2016; henceforth Guide), two separate concepts (i.e., multilingualism and plurilingualism) are defined, which broadly correspond to the societal and individual dimensions. ${ }^{3}$ According to the Guide, the difference between multilingualism and plurilingualism is seen multilingualism's reference "to the

3 They originate from the Common European Framework of Reference for Languages (CEFR, 2001, 2018, 2020), an essential document for language education in Europe that provides a basis for elaborating language syllabuses, curriculum guidelines, examinations, textbooks etc. 
presence of several languages in a given geographical area, regardless of those who speak them. In other words, the presence of two or more languages in an area does not necessarily imply that people in that area can use several of them; some use only one" (Beacco et al., 2016, p. 20, emphases are ours). In contrast, plurilingualism or plurilingual competence is defined as "the ability to use a plural repertoire of linguistic and cultural resources to meet communication needs or interact with people from other backgrounds and contexts, and enrich that repertoire while doing so" (Beacco et al., 2016, p. 20 , emphases are ours). The notion of plurilingual repertoire centres solely around language use and places the issue of language proficiency in the background. It consists of "resources which individual learners have acquired in all the languages they know or have learned, and which also relate to the cultures associated with those languages (languages of schooling, regional/minority and migration languages, modern or classical languages)" (ibid., emphases are ours). Such a perspective is essential because it acknowledges the value of developing an individual's plurilingual repertoire and does not focus solely on learning a specific language as the main factor in enabling communication. A plurilingual perspective supports the use of an individual's idiolect in institutional settings, where a particular dominant language(s) typically prevails.

Definitions of multilingualism and plurilingualism often reveal an overlap. When an individual's knowledge and ability to master (three or more) different languages (as opposed to monolingualism and bilingualism) are characterised in the scholarly literature published in English, they are semantically equal, except that 'multilingualism' is in this sense used especially in the American environment (e.g., Garcia, 2009), while 'plurilingualism' emerged largely from linguistic and intercultural conceptualisations proposed by the Council of Europe and the European Centre for Modern Languages (ECML) established at the Council of Europe (e.g., Coste et al., 2009). In particular, French linguists strictly distinguish multilingualism as the coexistence of several languages in society from plurilingualism, which puts the individual at the forefront and relates to his/ her life experiences with different languages and cultures (Grommes \& $\mathrm{Hu}$, 2014; Chen \& Helot, 2018).

Having radically changed how language learning and teaching practices have traditionally been conceived, another current perspective in 
multilingualism and bilingual education is translanguaging (Garcia \& Wei 2014). ${ }^{4}$ By focusing on speakers and their communication practices, translanguaging is concerned with the notions of code-switching (i.e., switching back and forth between two languages as autonomous and separate systems), especially code-meshing (i.e., mixing different local, vernacular, colloquial and world dialects of one language), yet stands apart from them in terms of its solid reference to the diverse bi-/multilingual language use of all actors in the pedagogical process, one which rises above the monoglossic perspective of the separate existence and use of two languages. Garcia (2009), who broadened the scope of the term, sees translanguaging as a process involving multiple discursive practices and refers to the complex language practices of individuals and communities and the pedagogical approaches to integrating these practices in formal school settings. When perceived as the standard and socially non-problematic mode of communication, translanguaging allows speakers to freely use the entire linguistic repertoire of their idiolects at any time, "without regard for watchful adherence to the socially and politically defined boundaries of named (and usually national and state) languages" (Otheguy et al., 2015, p. 283).

García and Kano remind us that translanguaging in education should be seen as:

a process by which students and teachers engage in complex discursive practices that include ALL the language practices of ALL students in a class to develop new language practices and sustain old ones, communicate and appropriate knowledge, and give voice to new sociopolitical realities by interrogating linguistic inequality. (García \& Kano 2014, p. 261, capitalised emphases by authors)

We believe this is a key aspect because such practices promote a deeper understanding of the learning content, which improves when the individual's whole linguistic repertoire is activated in the pedagogical process (Cenoz, 2013a). Further, introducing translanguaging practices into the classroom (or whole school environment) also establishes a new relationship

4 The term translanguaging was coined in Welsh by Cen Williams. It referred to a pedagogical practice of deliberately changing the language of input and output to increase understanding and augment one's activity in both languages. The idea of translanguaging was further developed to the idea of the general communicative practice of multilinguals (see Garcia \& Wei, 2014). 
in the social hierarchy of languages between the weaker language and the more dominant one. In education, the dominant language is the language of instruction (i.e., the language of schooling), which is usually also the language of school management. In many situations, the language of instruction is also the national language or an official regional language (i.e., the majority language). There are also languages with the dominant connotation that are a part of school curricula as additional languages (i.e., foreign languages - modern and ancient) and are recognised as socially more prestigious (Lambert, 1974) by the society and community due to various differently motivated ends. The weaker language/s, on the other hand, is/are usually the language/s of domestic communication (i.e., languages used at home) as well as the language/s acquired in early childhood.

Within translanguaging practices, the weaker language formally attains an equal (social) position as one of the constitutive languages in education and is explicitly designated and perceived as an asset (of the individual and community) and not as a weakness, burden or impediment to the pedagogical process and its actors. This circumstance holds profound social justice implications for the education of bilingual students. Whereas monolingual students are usually allowed the full use of their linguistic repertoire in assessment and learning, bilinguals are seldom permitted to do so, thereby keeping them silent and unengaged in teaching and assessment activities (Garcia \& Lin 2016, p. 6).

In this contribution, we want to reflect on the language context within the PYD perspective mainly in terms of the societal and individual dimensions of multilingualism; thus, we use the terms multilingualism and multilingual individuals generically while referring to the use of two or more languages (including bilingualism). ${ }^{5}$ While referring to the specific language competence of individual or educational/school approaches and

5 We are aware that many different terminologies about the languages that people speak in different social situations establish relationships between individual languages and reflect value views on languages and language education. One of the most common terminologies is $\mathrm{L}_{1}, \mathrm{~L}_{2}, \mathrm{~L}_{3}$... (i.e., first, second, third language) and denotes a sequential order of acquisition terminology but becomes problematic in simultaneous bilingual or trilingual acquisition cases. Dewaele (2010) proposes a terminology of L1 (the language of the first contact) and LX languages (languages of the multilinguals learnt after an $\mathrm{L}_{1}$ ); others suggest "additional languages" for those that are not connected to the initial socialisation of the speaker (Douglas Fir Group, 2016) or even reject the notion of $\mathrm{L}_{1}$ and $\mathrm{L}_{2}$ with the idea of the speaker's linguistic repertoire that consists of different features $\mathrm{F}(\mathrm{n})$ and belongs to the speaker's one (and not two) language system (Garcia \& Wei 2014). In the article, we use the LI, L2 ... LX notions while referring to the initial and additional languages. 
teaching practices that focus on developing a student's plurilingual repertoire, we employ as synonyms the terms plurilingual or multilingual competence, language multi-competence and plurilingual approaches, as well as translanguaging and translanguaging practices. The plurilingual approach to learning is inevitably connected to the notions of pluriculturality (i.e., the ability to participate in different cultures) and interculturality (the ability to experience otherness and diversity) as defined by the Guide (Beacco et al. 2016, p. 20) in the context of acquiring several languages. The development of plurilingual and intercultural awareness has become a leading educational goal of the Council of Europe (Council of Europe, 2019) and a fundamental principle of language education policies, whereas translanguaging practices in education have primarily been used in the USA and in Asia (Garcia \& Wei, 2014) and have recently also found a place in European research on multilingualism in education (Cenoz, 2009). Apart from developing language competencies and raising questions about the key role of languages in education, both approaches emphasise the role of education in the respect of cultural diversity and for ensuring social equity (cf. Beacco \& Byram, 2007). However, at the moment, the importance of integrating plurilingual approaches with education for democracy is stressed particularly in Europe (e.g., Reference Framework of Competences for Democratic Culture, 2020).

\section{The contemporary study of multilingualism and why interdisciplinary research is relevant}

We now briefly demonstrate the diversity in the contemporary study of multilingualism by summarising the approaches and findings found in Cenoz (2013b, pp. 7-10). ${ }^{6}$

Divided into two main groups and based on the individual and societal dimensions of multilanguage use, the author underlines the following areas of the modern study of multilingualism as particularly important.

Individual dimensions in the study of multilingualism involve: 1) the cognitive outcomes of multilingualism (e.g., positive effects of bi-/multilingualism on metalinguistic awareness and cognitive development, positive effects through lifespan such as the age-related decline in episodic

6 For each perspective in the field of study, the most influential authors are presented as well. We do not mention them here because we want to show the thematic breadth of multilingualism's treatment rather than individual directions. Later, when specific areas are mentioned, we name the relevant authors and their research. 
memory); 2) the relationship between language and thought in multilinguals (e.g. acquisition of additional languages and different factors that affect a person's thinking, perceptions, inner speech, and gesturing); 3) multilingual language processing (e.g., the mechanisms involved in comprehension and the productions of two or more languages, mental representations of the multilingual lexicon); 4) the multilingual brain (e.g., the study of characteristics of bilingual processing); and 5) cross-linguistic interaction (e.g., the complexity of code-switching).

Societal dimensions of multilanguage use are usually described in terms of: 1) social construction (e.g., languages as a set of resources and their socio-political implications); 2) multilingual identities (e.g., the individual's language choices from among the available linguistic resources as an act of his/her identity); 3) multilingual practices (e.g., various language practices in different contexts, such as pre-colonial and post-colonial non-Western contexts, language boundaries in urban contexts etc.); and 4) multilingualism and multimodality (e.g., language choices in the context of multimedia technology, communication channels, multimodal literacy).

Many areas of the contemporary study of multilingualism (on the individual and societal levels) often address multilingual phenomena in three highly relevant socio-historical macro contexts: globalisation, migrations, and new technology-based communication techniques. Particularly in the last 20 years, these contexts represent the universal social conditions that significantly influence multilinguals and their language choices while also affecting/shaping the general (societal) attitude to languages and their role in various micro contexts like education, research, media and politics as well as everyday communication practices in various professional and private settings.

Almost all of these perspectives bring valuable insights that can and should be considered while addressing the context of education. Yet, results stemming from research that combines methodologies and epistemologies from applied linguistics and social psychology are equally (if not more) significant for better understanding and acknowledging the role multilingualism plays in the context of inclusive education in the 21st century. Namely, a combination of diverse qualitative and quantitative approaches (see Comanaru \& Dewaele, 2015) adds to understanding of a range of aspects of multilingualism. It can provide ideologically less burdened, evidence-based and sound arguments for going beyond the monolingual perspective and a solid basis for developing policies and practices that can 
truly bring about the multilingual paradigm shift in the school environment. On the individual level, this shift unequivocally and explicitly defines the individual's entire language repertoire as an asset with cognitive, emotional, and personality development benefits. On the level of society, the shift regulates the school environment and pedagogical process by recognising this asset and ensuring an equal position for all languages as resources in the pedagogical process.

Results from interdisciplinary research combining social psychology and applied linguistics show that bi-/multilingualism does not affect intelligence but positively affects the metalinguistic awareness and cognitive development of children (Barac \& Bialystock, 2011) and holds advantages by way of creative behaviour and divergent thinking (Kharkhurin, 2008, 2010). These studies also show that, compared to monolinguals, bi-/multilingual teenagers and adults typically score higher for openness/open-mindedness, cognitive and cultural empathy, social initiative, suffer less from foreign-language anxiety, and see themselves as generally more competent in communication (Dewaele \& Oudenhoven, 2009; Dewaele \& Wei 2012). This supports the perspective that multilingualism is a complex multi-competence, which qualitatively differs from the competence of monolingual speakers and affects the shaping of personality (Cook 1992, Dewaele, 2016). On the societal level, this perspective offers a view of multilingualism not only as a phenomenon inextricably connected to one's identity but is a significant aspect in different social contexts. Such contexts range from construction and negotiation of identity through language in different social interactions to the various issues related to acknowledging the diverse multilingual and multicultural background of multilinguals in different micro contexts like education, professional and private life, and active citizenship.

It is important to mention a developing interdisciplinary research perspective in multilingualism that connects applied linguistics with positive psychology. In a 2014 article, Mercer and MacIntyre introduced the field of positive psychology (PP) and the implications it holds for research into the practical, human and social dimensions of language learning, notably of second language acquisition (SLA). The general idea of PP that it is vital to study how people thrive and flourish as well as how to increase their (character) strengths and virtues becomes relevant when these elements are studied in the context of institutions, such as classrooms, schools, and language policies that explicitly enable the expression and development of strengths (Mercer \& MacIntyre, 2014). This new holistic view of foreign 
language learning was inspired by PP in the sense that it moved away from a sole focus on negative emotions (i.e., foreign-language classroom anxiety - FLCA) and also included learners' positive emotions (i.e., foreign-language enjoyment - FLE,) as an essential part of the language learning process (e.g., Dewaele et al., 2017; Dewaele \& MacIntyre 2014; Resnik \& Dewaele 2020).

\section{Multilingualism in the migrations context - some points to consider}

The global political and economic development over the last 25 years, which has given ever more social, political or economic reasons for people to leave their home country, has made studies on acculturation become particularly relevant, with a number of approaches and models emerging to investigate "the way people accommodate the heritage and the mainstream culture in which they are immersed" (Panicacci \& Dewaele, 2017, p. 4). As mentioned, the context of migration is also one of the three socio-historical macro contexts in contemporary multilingualism research that study various processes and factors in immigrants' re-socialisation in a new (i. e., host/majority) language and culture, and how they shape their personalities and identities. In complex processes of negotiating their multiple cultural identities (Benet-Martinez \& Haritatos, 2005), immigrants' multiple-language use plays an essential role in terms of linguistic preferences in their everyday interactions within the host/majority language speaking community and expressing emotions (Panicacci \& Dewaele, 2017). The need to adapt (i.e., learn new skills and absorb new information) to a new environment combined with the experience of loss, cultural differences and problems of constructing social networks within the majority and ethnic groups can cause different behaviour and emotional difficulties (e.g. low esteem with higher depression and anxiety among migrant children (Diler et al., 2003), which among others also manifest as communicative anxiety and a negative influence on linguistic competence. Studies of language anxiety in the immigrant context (Sevinç \& Backus, 2017, Sevinç \& Dewaele, 2016;) reveal its linguistic and socioemotional complexity, ranging from immigrants' identity issues created by linguistic difficulties and their insecurity of knowledge and use of either the majority language (ML) or the heritage language (HL), and are closely linked to linguistic and social inequality as well as perceptions of native-likeness, sense of belonging, and social exclusion regarding the ethnic and local (i.e. mainstream) community. 
On the other hand, studies investigating the impact of bicultural identity, bilingualism and social context found beneficial psychological outcomes of bilingualism (Chen et al., 2008). Panicacci (2019) combined psychological and linguistic variables in her study on the link between the languages migrants use in private and emotional domains and their sense of belonging to the heritage and the host culture. Supported by an extensive overview of previous research of acculturation processes, emotion expression, and language perception, the results show that it is not the portion of life spent in the country that helps boost migrants' acculturation level to the host country but their emotional, affective, mental and linguistic engagement with the local community. One of the crucial roles in this identity-reshaping process is played by language use, which tends to entail a hybrid of different languages ( $\mathrm{L} 1$ and LX) and cultures. When a specific language (L1 or LX) is used in a communicative situation, it helps migrants either maintain a solid connection with their cultural roots or develop a new affiliation for the new culture. In the complex puzzle of hybrid migrant identities, cultural orientations, and life situations, Panicacci's research shows that both (or more) languages are used for expressing emotions (not only L1 as the ordinary language of the heart) and even considering LX a dominant and emotional language does not necessarily cause migrants to disengage from their heritage.

For a paradigm shift in the perspective of social change that is brought by the immigration and acculturation and shapes the personality of young people as well, the research "Third Culture Kids" (TCKs) or "Cross-Cultural Kids" (CCKs) ${ }^{7}$ is also relevant by showing the potential in the development of young immigrants' own unique life patterns due to the complexity of their life experiences. In a study of links between multilingualism, multiculturalism, acculturation, and the personality profiles of TCKs, Dewaele and Oudenhoven (2009) discovered that out of 79 teenagers in London, those who had been born abroad and spent their childhood in London (i.e., TCKs) scored significantly higher for Openmindedness and Cultural Empathy and significantly lower for Emotional Stability as measured by the

7 The concept was introduced from sociology by Useem and Useem (1967) and extended by Pollock and Van Reken (2001): "A Third Culture Kid (TCK) is a person who has spent a significant part of his or her developmental years outside the parents' culture. The TCK frequently builds relationships to all of the cultures, while not having full ownership in any. Although elements from each culture may be assimilated into the TCK's life experience, the sense of belonging is [often] in relationship to others of similar background" (Pollock \& Van Reken, 2001, p. 19). 
Multicultural Personality Questionnaire developed by van Oudenhoven and van der Zee (2002). Based on the results, which suggested that specific personality dimensions of young teenagers are linked to their multilingualism and multiculturalism, the authors contend the low emotional stability of TCKs might be connected to the stressful process of linguistic and cultural acculturation. The results also show that the immigration experience of fitting in makes TCKs stronger, more open-minded and unprejudiced. The need to develop an awareness of different cultural norms and values might come from the realisation that their values and attitudes may not be shared by the people around them (Dewaele \& Oudenhoven, 2009, p. 14). In addition, the authors suggest the need to change our way of looking at language knowledge in the immigrant context:

Rather than focusing on aspects in which the acculturating group is expected to be 'deficient' compared to control groups, a more global description of the acculturating group is needed, including variables in which it may score better than the control group. In other words, by focusing exclusively on the pain, researchers have omitted to consider the potential gain of TCKs. (Dewaele \& Oudenhoven, 2009, p. 7)

The research approach that focuses on the individual's strengths and virtues and understands bi-/multilingualism as an asset in personal development is close to the PYD research of the strengths of immigrant adolescents (Forman et al., 2009). We believe that the idea of recognising immigrants' potential for positive development, together with bilingualism, biculturalism and integrated identities "as assets to their communities and bases of their positive contributions to civil society" (Lerner et al., 2012, p. 317 ), creates the possibility of collaborative research between PYD and multilingualism studies.

\section{PYD and language context - the relevance of studying multilingualism for the research into thriving}

The connecting of multilingualism with the field of psychology, including positive psychology, is therefore not new. In particular, the association of social psychology with research in L2 points to several possibilities within thematic links, such as teaching and learning of language, motivation and cognitive development, or multilingualism and emotions (Dewaele et al., 2019). In our review of the literature, multilingualism in the PYD perspective 
has not been explicitly addressed within its models and approaches (see, for example, Benson et al., 2006; Shek et al., 2019). The significance of the language(es) can be found in studies on thriving among immigrant youth. In these studies, bilingualism is seen as part of a trans/-bicultural and integrated identity without emphasis on the specifics of the language used in acculturation processes (Lerner et al., 2012). Moreover, some intervention programmes in the USA focus on refugees and immigrants, expressly mentioning the category of language and conceptual bases that seem to originate in translanguaging. Working with youth in these programmes is based on a conceptualisation of the four unique adolescent immigrant assets, which involve: 1 ) the protective strengths of values of the family's culture of origin; 2) bilingualism as an asset in an increasingly global world; 3) migration-related struggles of the family as a means of adolescents' empowerment due to their quicker language adaptation; and 4) balancing the two cultures as a source for developing resiliency, flexibility and skills to assess human interactions (Morland et al., 2006/2009; Easter \& Refki, 2004).

However, the holistic view of the languages, which embodies the theoretical study of multilingualism, has not been included in the theory, research and applications of the PYD perspectives. This would mean including in the PYD model the multilingual perspective of language context, where multilingualism results in individuals' multi-competence with broader effects than knowledge of the language itself (Dewaele, 2016). According to Cenoz (2013a), such a perspective has three main dimensions: 1) the multilingual speaker (the use of all languages at the individual's disposal as a resource with dynamic proficiency according to their communication needs); 2) the whole linguistic repertoire (i.e., the hybridity of communication with soft boundaries between linguistic resources); and 3) the social context (i.e., the interaction between multilingual speakers and the communicative context).

This article does not aim to theoretically and empirically place multilingualism in PYD, but to trigger interest in the study of PYD from the multilingual perspective with possible investigations of the language context's relevance relying on concepts of the individual's language repertoire and self-perceived language multi-competence (i.e., plurilingual competence) and perceptions of languages for the empirical study of positive youth development, and the connection between how the languages are perceived and different PYD contexts (e.g. school, immigrations). 
To establish a solid (theoretical and methodological) nexus between language context and the PYD perspective, theoretical and empirical bases of the study of multilingualism should be considered (e.g., Dewaele \& Pavlenko, 2001-2003; Dewaele \& Oudenhoven, 2009; Dörnyei, 2007; van Oudenhoven \& van der Zee, 2002). The combined approach of incorporating linguistic variables in the PYD research design as part of a sociobiographical questionnaire or as an independent contextual element might include questions about oral and written proficiency in different languages, the frequency and specific contexts/situations of language use, perception of languages like language dominance and emotionality, emotion expression, and language anxiety. Further, quantitative findings should be supported with qualitative research (e.g., interviews) since that may provide valuable in-depth comments. Thus, it can better reveal the interconnections between the individual's self-perceived language multi-competence, their perceptions, motivations and attitudes, and the specifics of their language use in various groups or with individuals (parents, family, peers, classmates, teachers, adults, migrant/non-migrant background etc.) in different social contexts (e.g., home, school, free-time activities, community engagement).

The existing interdisciplinary connections between social psychology and multilingualism already extensively highlight the social, cognitive and emotional aspects of language use, which might be necessary for the holistic approaches within PYD models such as Lerner's 5/6Cs and Benson's 40 developmental assets. Since these two perspectives provide one of the main conceptual bases for the PYD-SI model, identifying points of intersection that allow the possibility for linking language context with contexts and indicators of the thriving and multilingualism's individual or societal dimensions might be helpful.

PYD is framed by the relational developmental systems model of human development (Overton, 2015), whereby mutually significant relations between the individual and their multiple contexts constitute the fundamental process of human development across the lifespan. Based on the assumption that all young people have strengths, the PYD perspective "seeks to identify the individual attributes of youth that, when coupled with resources for healthy growth present in their social ecologies (e.g. their families, school, faith institutions, or community-based youth programs), lead to thriving (i.e., to well-being and health) across the adolescent decade" (Lerner et al., 2012, p. 307). In such interaction, the role of contexts as 
developmental assets (Benson et al., 2011) is usually emphasised, while the ${ }_{5} \mathrm{Cs} / 6 \mathrm{Cs}$ outcomes or indicators of positive youth development outcomes (Lerner et al., 2005) are also recognised. The forty developmental assets (Benson, 2003, pp. 198-199) which can facilitate positive youth outcomes pertain to social relationships, interactions, experiences, and developmental processes. In four main categories, they are divided into 20 external assets (i.e., environmental, contextual and relational features of socialising systems) and 20 internal assets (i.e., skills, competencies and values). The external asset categories include support (family support, positive family relationships, other relationships with adults, a caring neighbourhood, a favourable school climate, parental involvement in schooling), empowerment (community values, helping others, security), boundaries and expectations (those within the family, those within school, those within neighbourhoods, adult role models, positive peer influence, high expectations) and constructive use of time (creative activities, youth programmes, religious community, time spent at home). The internal asset categories cover commitment to learning (motivation to succeed, learning commitment, homework, connection to the school, reading for pleasure), positive values (care, equality and social justice, integrity, honesty, responsibility, self-control), social competencies (planning and decision-making, interpersonal competencies, cultural competencies, appropriate conflict resolution), and positive identity (self-esteem, positive opinion of personal future). When youth's strengths are aligned with developmental assets, the positive development that results can be operationalised by the "Five Cs"/5Cs - Competence, Confidence, Connection, Character and Caring (Bowers et al., 2010, p. 721). Competence represents a positive view of one's actions in domain-specific areas, including social, academic, cognitive and vocational ones. Social competence pertains to interpersonal skills (e.g., conflict resolution), cognitive competence to cognitive abilities (e.g., decision making), academic competence to school grades, attendance, and test scores, whereas vocational competence involves work habits and career choice explorations, including entrepreneurship. Confidence is defined as an internal sense of overall positive self-worth and self-efficacy, one's global self-regard, as opposed to domain-specific beliefs. Connection denotes an individual's positive bonds with people and institutions that are reflected in bidirectional exchanges between the individual and their peers, family, school and community, in which both parties contribute to the relationship. Character represents a person's respect for societal and cultural rules, the possession of 
standards for correct behaviours, a sense of right and wrong (morality), and integrity. Caring indicates a sense of sympathy and empathy for others. In addition, it has been shown that when adolescents manifest these $5 \mathrm{Cs}$ over time, they also contribute to self, family, community, and civil society (i.e., Contribution as the sixth C; see Lerner et al., 2005). The link between the two constructs of PYD and specific areas of multilingualism can be specified as a study of the relevance of linguistic factors in the understanding of the strengths and productivity of adolescents. Since language diversity nowadays represents an omnipresent and particularly visible social phenomenon (Aronin \& Singleton, 2008) and is also an inevitable part of the educational process (i.e., as a communication practice and learning topic of non-formal and formal educational settings), the use of at least two or multiple languages represents a large part of the socio-cultural environment and different kinds of the interaction of youth. Adolescents in their life span can at the same time communicate with parents, family, teachers, peers, friends, advisers, trainers etc. in their first languages, languages of schooling, languages of environment. In school or as part of informal activities, they also learn more than one language, ranging from their first languages, languages of schooling, languages of the environment, to foreign languages. Further, the languages adolescents use or learn at a very different level of proficiency and regarding which they have different perceptions and emotional attitudes to establish part of a wider dynamic socio-cultural hierarchy. They are thus constantly subjected to social foregrounding and backgrounding as elite, nationally, culturally desired, and expected languages or, in contrast, by being marginalised and, due to socio-political reasons suppressed, they are socially or culturally (e.g., as an implicit part of educational policies) seen as less important languages. These individual and social contexts of language use reshape youth's cultural identity and affect their personality and cognitive abilities. They also enable the development of a variety of individuals' linguistic repertoires, as demonstrated through their dynamic multilanguage competence as a means of interaction in diverse communicative situations. From this perspective, the research into plurilingual repertoires, language multi-competence, translanguaging as an inclusive educational practice, different aspects of language anxiety as well as studies that investigate the role of emotions and feelings in (foreign) language could be linked to the study of PYD's developmental assets and ${ }_{5} \mathrm{Cs}$ within constructs that relate to social relationships, interactions, experiences, and developmental processes. 
Since interdisciplinary studies of multilingualism shed light on different (micro and macro) social contexts of language use (e.g., Cenoz 2013b; Comanaru \& Dewaele, 2015; Kramsch, 2010) as well as empirically investigate multilingualism's positive impact on individuals' social activation, emotionality, and personal development (e.g., Dewaele \& Pavlenko 20022003; Panicacci, 2019; Resnik \& Dewaele, 2020), the study of their connection to the external and internal assets might reveal the impact of the individual's (multi)language competence on their overall experience with the resources for positive development and also give better insight into the availability of contextual resources to young people. For instance, school environments that successfully incorporate translanguaging and plurilingual practices in their inclusive approaches (e.g., Beacco et al., 2016; Garcia, 2009) might be recognised by youth as institutions that offer more support and empowerment. The self-perceived multi-competence of youth as one of the elements of greater confidence (Dewaele, 2016) could be linked with their experience of commitment to learning and positive values. Different aspects of language anxiety (i.e., heritage, majority, foreign-language anxiety) might be linked to young people's experience with boundaries and expectations as well as positive identity with a special focus on migrant (Sevinç \& Backus, 2017; Sevinç \& Dewaele, 2016), school (Dewaele et al., 2017), family and community contexts (Panicacci, 2019). Similarly, within the ${ }_{5} \mathrm{Cs}$, research on the cognitive outcomes of multilingualism (Barac \& Bialystock, 2011; Kharkhurin, 2008, 2010), the role of positive emotions in language anxiety (e.g., Dewaele et al., 2019; Dewaele \& MacIntyre 2014; Resnik \& Dewaele 2020), the effect on individuals' personality in terms of open-mindedness, cultural empathy, and emotional stability (Dewaele 2016; Dewaele \& Wei 2012) and the value of individuals' multilingual/multicultural identity for the community (Wei et al., 2002) may point to several indicators of positive development.

The migrant context might be particularly interesting for the study of positive youth development that incorporates multilingualism research. In the PYD - SI MODEL, migration status is identified as a risk factor related to negative youth development outcomes (e.g. risky or problem behaviour, emotional difficulties, problems with school functioning) and often come as a result of the interplay between external and internal factors in adolescents' processes of acculturation as well as adjusting to the individual and social transitions of their age period (Strohmeier \& SchmittRodermund, 2008; Suarez-Orozco \& Suarez-Orozco, 2001). However, PYD 
studies that focus on the thriving of immigrant youth and stress the importance of immigrants' multilingual and multicultural skills as a resource for their new communities (Lerner et al., 2012), combined with studies that consider multilingualism in the context of immigrants (e.g. Cenoz 2013a; Dewaele \& Stavans, 2014; Panicacci 2019; Sevinç \& Backus, 2017; Sevinç \& Dewaele, 2016) might open up prospects for the study of language context with the positive youth development. Particularly when connecting the experience of developmental assets or positive outcomes with the findings of interdisciplinary research on immigrant adolescents, which show the positive effects of multilingualism/multiculturalism on personal development (e.g., Dewaele \& Oudenhoven, 2009), we might see the intersection of findings that point in the same direction: ones that confirm the presence of strengths in immigrant youth arising from the specificity of their individual and social context, as determined by their multilingual/multicultural identity and formed in the acculturation process.

Below, we present two tables that provide an overview of the main areas of intersection between the two PYD perspectives (developmental assets and the ${ }_{5} \mathrm{Cs}$ ) and the main findings from the study of multilingualism. The label Dimensions of multilingualism represents its holistic conception from sociolinguistic research that moves beyond the sole linguistic realm and sees language multi-competence as the result of the dynamic growth of individual multilingualism, which "affects not just an individual's cognition but also that individual's personality" (Dewaele, 2016, p. 2). From this perspective, we indicate points of intersection where we believe the 'speaking/using' of multiple languages (i.e., language knowledge, language use, self-perceived language proficiency) as a variable might become relevant for the study of the strengths of all youth and the fostering of their positive development. 
Table 1: Intersections of developmental assets and multilingualism research.

\begin{tabular}{|c|c|}
\hline $\begin{array}{l}\text { 1. Support } \\
\text { 2. Empowerment } \\
\text { 3. Boundaries and expectations } \\
\text { 4. Constructive use of time }\end{array}$ & $\begin{array}{l}\text { - The benefits of an individual's dynamic use of } \\
\text { a plurilingual repertoire in different social con- } \\
\text { texts } \\
\text { - Translanguaging practices and plurilingual } \\
\text { approaches as part of a multilingual/multicul- } \\
\text { tural school environment } \\
\text { - Plurilingual competence as a means of soci- } \\
\text { al activation } \\
\text { - Language anxiety and the role of positive and } \\
\text { negative emotions in foreign-language learning } \\
\text { and teaching (FLA) } \\
\text { - The role of language anxiety in the accultura- } \\
\text { tion process (MLA, HLA) }\end{array}$ \\
\hline Internal Categories & Dimensions of multilingualism \\
\hline $\begin{array}{l}\text { 1. Commitment to learning } \\
\text { 2. Positive values } \\
\text { 3. Social competencies } \\
\text { 4. Positive identity }\end{array}$ & $\begin{array}{l}\text { - Effect of multilingualism on personal develop- } \\
\text { ment (e.g., open-mindedness, cultural empathy, } \\
\text { emotional stability) } \\
\text { - Effect of multilingualism on self-perceived } \\
\text { communication and interactive skills } \\
\text { - The role of multilingual/multicultural identi- } \\
\text { ty in society }\end{array}$ \\
\hline
\end{tabular}

Table 2: Intersections of the 5 Cs and multilingualism research.

\begin{tabular}{|c|c|}
\hline $5 / 6 \mathrm{Cs}$ & Dimensions of multilingualism research \\
\hline $\begin{array}{l}\text { 1. Competence } \\
\text { 2. Confidence } \\
\text { 3. Connection } \\
\text { 4. Character } \\
\text { 5. Caring } \\
\text { 6. Contribution }\end{array}$ & $\begin{array}{l}\text { - Cognitive outcomes of multilingualism } \\
\text { - Perception of languages and emotion, langu- } \\
\text { age anxiety } \\
\text { - Effect of multilingualism on personal deve- } \\
\text { lopment (e.g., open-mindedness, cultural em- } \\
\text { pathy, emotional stability) } \\
\text { - Individual multilingual/multicultural identity } \\
\text { as an asset to the community }\end{array}$ \\
\hline
\end{tabular}

\section{Conclusion}

In this chapter, we tried to outline the relevance held by language context for positive youth development with a focus on multilingualism, which embraces a holistic view of languages in terms of the individual or societal dimension. Multilingualism is a phenomenon that has attracted research attention in the last 20 years and is becoming a vital part of critical social agendas such as migration, education, democratic culture, and as an individual multi-competence for everyday interactions.

After considering the interdisciplinary research on multilingualism's positive influence on cognitive development, empathy, social initiative, and 
foreign-language anxiety, as well as studies that investigated the role played by emotions and feelings in (foreign) language learning, including the PP perspective, we proposed some points of intersection with the PYD perspective as well. More attention to language context could extend the PYD approach's usefulness to help better understand the strengths of the young people, especially those with an immigrant background.

In the first part of the article, we described the main aspects of multilingualism, the complexity of the concept on the levels of scope, terminology and its successful integration with research in the social psychology field. At the same time and via the concept of translanguaging and plurilingualism, we also outlined multilingualism's involvement in education, chiefly as a basis for inclusive education. Although the school environment, at least in Slovenia, is often still perceived as monoglossic with Slovenian as both the language of schooling and the majority language, the presence of different languages at school (as a learning content or means of communication) and the growing number of students with an immigrant background proves that we cannot speak of a monolingual environment. Policies and practices that only aim to ensure optimised conditions for the language of schooling and the language of the majority, while acknowledging other languages merely at the level of elite multilingualism (i.e., languages that hold socio-cultural significance in the educational context), will inevitably exclude a large share of the population for these speakers to be able to mobilise their entire language repertoires to successfully acquire knowledge and skills, interact better and positively contribute to civil society - as interdisciplinary research on multilingualism's benefits clearly shows. Nevertheless, this paradigm shift can only happen when we recognise and systematically support the existence of a plurilingual repertoire in the school environment when we adopt the multilingual classroom as the norm. From a global perspective, Christine Hélot and Muiris Ó Laoire explain what this means for language policy:

Adopting the multilingual classroom as the norm means acknowledging diversity and changing identities in migration contexts, recognising the potential of the multilingual classroom ecology in language education, transcending the traditional socio-cultural barriers in the implementation of a multilingual curriculum, defending the positioning of teachers' policies, exploiting students' metalinguistic awareness at the pedagogical level 
and redefining power relations in the case of minority languages in the language constellation. (Hélot \& Laoire, 2001, p. XVIII)

We include this long passage above because it underlines the idea of recognising the potential of the school environment/context, which is also the focus of the PYD perspective and was presented in part two of this article. It seems that the addition of a multilingualism perspective can contribute to PYD precisely by revealing the perhaps hitherto overlooked dimension of the linguistic potential of youth. In addition, the contextualisation of the PYD model with plurilingual and translanguaging practices might offer a valuable tool to help teachers and learners become aware of their strengths and develop efficient strategies for expanding and using their language repertoires, which may help them in educational settings to improve their teaching and learning.

In the second part of the article, we indicated the points common to both areas and showed the potential of a collaborative approach by presenting intersection of concepts and research results. While many issues remain unsettled as to how to properly link multilingualism and PYD, especially on the methodological level, this was not the paper's purpose. Nevertheless, the interdisciplinary multilingualism research already shows the language context is significant for investigating the strengths of immigrant youth as part of their multilingual/multicultural identities. By understanding language characteristics as an asset, the significance of multilingualism should be indicated in the framework of socially just policies or prevention programmes with the development of a multilingualism-friendly environment as one of those fostered conditions that promote adolescents' attributes of thriving. As Jean-Marc Dewaele, who have we referred to many times, writes below about the line of extensive research on the connections between multilingualism and personality:

In short, it seems that learning a foreign language tends to make you a better person, more creative, more open-minded, more empathic, more emotionally stable, more sociable, more likely to enjoy foreign language classes, better equipped to learn new languages and less anxious in communication. (Dewaele, 2016, p. 13)

\section{Literature}

Aronin, L., Singleton, D. (2008). Multilingualism as a new linguistic dispensation. International Journal of Multilingualism, 5, 1-16. https://doi. org/10.2167/ijmo72.0 
Barac, R., Bialystok, E. (2011). Research timeline: Cognitive development of bilingual children. Language Teaching 44, 36-54. https://doi.org/10.1017/ So261444810000339

Beacco J.-C., Byram M. (2007). From linguistic diversity to plurilingual education: Guide for the development of language education policies in Europe. Council of Europe.

Beacco, J.-C., Byram, M., Cavalli, M., Coste, D., Egli Cuenat, M., Goullier, F., \& Panthieret, J. (2016). Guide for the development and implementation of curricula for plurilingual and intercultural education. Council of Europe.

Benet-Martinez, V., Haritatos, J. (2005). Bicultural identity integration (BII): Components and psychological antcedents. Journal of Personality 73, 1015-1050. https://doi.org/10.1111/j.1467-6494.2005.00337.x

Benson, P. L. (2003). Developmental assets and asset-building community: Conceptual and empirical foundations. In R. M. Lerner \& P. L. Benson (Eds.), Developmental assets and asset building communities: Implications for research, policy, and practice (pp. 19-43). Springer.

Benson, P. L., Scales, P. C., Hamilton, S. F., \& Sesma, A., Jr. (2006). Positive Youth Development: Theory, Research, and Applications. In R. M. Lerner \& W. Damon (Eds.), Handbook of child psychology: Theoretical models of human development (pp. 894-941). John Wiley \& Sons Inc.

Benson, P. L., Scales, P. C., \& Syvertsen, A. K. (2011). The contribution of the developmental assets framework to positive youth development theory and practice. Advances in Child Development and Behavior 1(41), 197-230. https://doi.org/10.1016/B978-0-12-386492 5.00008-7

Bowers, E. P., Li, Y., Kiely, M. K., Brittian, A., Lerner, J. V., \& Lerner, R. M. (2010). The Five Cs model of positive youth development: a longitudinal analysis of confirmatory factor structure and measurement invariance. Journal of youth and adolescence, 39(7), 720-735. https://doi.org/10.1007/ s10964-010-9530-9

Burke, P. (2004). Languages and Communities in Early Modern Europe. Cambridge University Press.

Cenoz, J. (2009). Towards multilingual education: Basque educational research from an international perspective. Multilingual Matters.

Cenoz, J. (2013a). The influence of bilingualism on third language acquisition: Focus on multilingualism. Language Teaching, 46, 71-86. https://doi. org/10.1017/So261444811000218

Cenoz, J. (2013b). Defining multilingualism. Annual Review of Applied Linguistics, 33, 3-18. https://doi.org/10.1017/So26719051300007X 
Chen, S. X., Benet-Martínez, V., \& Harris Bond, M. (2008). Bicultural identity, bilingualism, and psychological adjustment in multicultural societies: Immigration-based and globalization-based acculturation. Journal of Personality 76 (4), 803-838. https://doi.org/10.1111/j.1467 6494.2008.00505.X

Chen Y.-Z., Hélot, C. (2018) Notion of Plurilingual and Pluricultural Competence. Language Education and Multilingualism 170 (1), 168-187.

Comanaru, R.-S., Dewaele J.-M. (2015). A bright future for interdisciplinary multilingualism research. International Journal of Multilingualism, 12(4), 404-418. https://doi.org/10.1080/14790718.2015.1071016

Cook, V. (1992). Evidence for multicompetence. Language Learning, 42, 557591. https://doi.org/10.1111/j.1467-1770.1992.tbo1044.X

Coste, D., Moore, D., \& Zarate, G. (2009). Plurilingual and Pluricultural Competence: with a

Foreword and Complementary Bibliography. Council of Europe.

Council of Europe. (2019). Council recommendation of 22 May 2019 on a comprehensive approach to the teaching and learning of languages (2019/C 189/o3).

Council of Europe. https://eur-lex.europa.eu/legalcontent/EN/TXT/?uri=uriserv: OJ.C_.2019.189.01.0015.01.ENG\&toc=OJ:C:2019:189:TOC

Council of Europe. (2001, 2018, 2020). Common European Framework of Reference for

Languages: Learning, teaching, assessment - Companion volume. Council of Europe Publishing. www.coe.int/lang-cefr

Council of Europe. (2020). Reference Framework of Competences for Democratic Culture. Council of Europe Publishing. https://rm.coe.int/prems-007021-rfcdc-competences-for democratic-culture-and-the-importan/1680a217cc

Dewaele, J. M. (2010). Emotions in multiple languages. Palgrave Macmillan.

Dewaele, J.-M. (2016). Multi-competence and personality. In V. Cook \& L. Wei (Eds.), The Cambridge Handbook of Linguistic MultiCompetence (Cambridge Handbooks in Language and Linguistics, pp. 403-419). Cambridge. https://doi.org/10.1017/CBO9781107425965.019

Dewaele, J., Chen, X., Padilla, A.M., \& Lake, J.W. (2019). The Flowering of Positive Psychology in Foreign Language Teaching and Acquisition Research. Frontiers in Psychology, 10, 1-13. https://doi.org/10.3389/fpsyg.2019.02128

Dewaele, J.-M., MacIntyre, P. D. (2014). The two faces of Janus? Anxiety and enjoyment in the foreign language classroom. Studies in Second Language Learning and Teaching, 4(2), 237-274. https://doi.org/10.14746/ssllt.2014.4.2.5 
Dewaele, J.-M., Stavans, A. (2014). The effect of immigration, acculturation and multicompetence on personality profiles of Israeli multilinguals. International Journal of Bilingualism, 18(3), 203-221. https://doi. org/10.1177/1367006912439941

Dewaele, J.-M., van Oudenhoven, J. P. (2009). The effect of multilingualism/ multiculturalism on personality: no gain without pain for Third Culture Kids? International Journal of Multilingualism, 6(4), 443-459. http://dx. doi.org/10.1080/14790710903039906

Dewaele, J.-M., Pavlenko, A. (2001-2003). Web questionnaire 'Bilingualism and Emotions'. University of London.

Dewaele, J., Wei, L. (2012). Multilingualism, empathy and multicompetence. International Journal of Multilingualism, 9, 352-366. https://doi.or g/10.1080/14790718.2012.714380

Dewaele, J.-M., Witney, J., Saito, K., \& Dewaele, L. (2018). Foreign language enjoyment and anxiety in the FL classroom: The effect of teacher and learner variables. Language Teaching Research, 22(6), 676-697. https://doi. org/10.1177/1362168817692161

Diler, R.S., Avci, A., \& Seydaoglu, G. (2003). Emotional and behavioural problems in migrant children. Swiss Medical Weekly, 133, 16-21.

Dörnyei, Z. (2007). Research methods in applied linguistics: Quantitative, qualitative, and mixed methodologies. Oxford University Press.

Douglas Fir Group. (2016). A transdisciplinary Framework for SLA and a Multilingual World. Modern Language Journal, 100, 19-47. https:/doi. org/10.1111/modl.12301

Easter, M., Refki, D. (2004). Practice Matters: Creating Successful Programs for Immigrant Youth. A quarterly publication by Cornell University. http:// www.actforyouth.net/resources/pm/pm_creatingsuccess_1204.pdf

Franceschini, R. (2011). Multilingualism and Multicompetence: A Conceptual View. The Modern Language Journal, 95(3), 344-355. https://doi. org/10.1111/j.15404781.2011.01202.x

Forman, Y., Du, D., Kiely, M., Carrano, J., \& Lerner, R. (2009). We're Here, We're Hopeful, and We Can Do Well: Conceptions and Attributes of Positive Youth Development among Immigrant Youth. Journal of Youth Development (4)1, 1-16 https://doi.org/https://doi.org/10.5195/jyd.2009.271

Garcia, O. (2009). Bilingual education in the 21st century: A global perspective. Blackwell. 
García, O., Kano, N. (2014). Translanguaging as process and pedagogy: Developing the English writing of Japanese students in the US'. In Conteh, J. \& Meier, G. (eds.) The Multilingual Turn in Languages Education: Opportunities and Challenges (pp. 258-277). Multilingual Matters.

García, O., Lin, A. M. Y. (2016). Translanguaging in bilingual education. In O. García, A. M. Y. Lin, \& S. May (Eds.), Bilingual and Multilingual Education (Encyclopedia of Language and Education) (pp. 117-130). Springer.

García, O., Wei, L. (2014). Translanguaging: Language, Bilingualism and Education. Palgrave Macmillan.

Geldhof, J. G., Bowers, E. P., Mueller, K. M., Napolitano, C. M., Schmid Callina, K., \& Lerner, R. M. (2014). Longitudinal analysis of a very short measure of Positive Youth Development. Journal of Youth and Adolescence, 43(6), 933-949. https://doi.org/10.1007/s10964-014-0093-Z

Grommes, P., Hu, A. (Eds.) (2014). Plurilingual Education: Policies-practiceslanguage development. John Benjamins.

Hélot, C., Laoire, M. (2011). Language Policy for the Multilingual Classroom. Multilingual Matters. https://doi.org/10.21832/9781847693686

Herzog-Punzenberger, B., Le Pichon-Vorstman, E., \& Siarova, H., (2017). Multilingual Education in the Light of Diversity: Lessons Learned, NESET II report. Publications Office of the European Union. https://doi. org/10.2766/71255

Kharkhurin, A. V. (2008). The effect of linguistic proficiency, age of second language acquisition, and length of exposure to a new cultural environment on bilinguals' divergent thinking. Bilingualism: Language and Cognition, 11 (2), 225-243. https://doi.org/10.1017/S1366728908003398

Kharkhurin, A. V. (2010). Bilingual verbal and nonverbal creative behavior. International Journal of Bilingualism, 14 (2), 1-16. https://doi. org/10.1177\%2F1367006910363060

Kemp, C. (2009). Defining multilingualism. In L. Aronin \& B. Hufeisen (Eds.), The exploration of multilingualism: Development of research on L3, multilingualism, and multiple language acquisition (pp. 11-26). John Benjamins.

Kramsch, C. (2009). The Multilingual Subject (Oxford Applied Linguistics). Oxford University Press.

Lambert, W. E. (1974). Culture and language as factors in learning and education. In F. E. Aboud, \& R. D. Mead (Eds.), Cultural factors in learning and education Fifth Western Washington Symposium on Learning. 
Lerner, R. M., Lerner, J. V., Almerigi, J., Theokas, C., Phelps, E., Gestsdottir, S., et al. (2005). Positive youth development, participation in community youth development programs, and community contributions of fifth grade adolescents: Findings from the first wave of the 4-H Study of Positive Youth Development. Journal of Early Adolescence, 25(1), 17-71. https://doi.org/10.1177\%2Fo272431604272461

Lerner, R. M., Lerner, J. V., Bowers, E. P., \& Lewin-Bizan, S. (2012). Thriving among immigrant youth: Theoretical and empirical bases of positive development. In A. S. Masten, K. Liebkind, \& D. J. Hernandez (Eds.), Realizing the potential of immigrant youth (pp. 307-323). Cambridge University Press. https://doi.org/10.1017/CBO9781139094696.016

Mercer, S., MacIntyre, P. D. (2014). Introducing positive psychology to SLA. Studies in Second Language Learning and Teaching, 4(2), 153172. https://doi.org/10.14746/ssllt.2014.4.2.2

Morland, L., Rose, J., \& Schmidt, S. (2006/2009). Growing up in a new country: A positive youth development toolkit for working with refugees and immigrants. https://brycs.org/

Otheguy, R., García, O., \& Reid, W. (2015). Clarifying translanguaging and deconstructing named languages: A perspective from linguistics. Applied Linguistics Review, 6(3), 281-307. https://doi.org/10.1515/applirev-2015-0014

Overton, W. F. (2015). Processes, relations, and relational-developmental-systems. In W. F.

Overton, P. C. M. Molenaar, \& R. M. Lerner (Eds.), Handbook of child psychology and developmental science: Theory and method (pp. 9-62). John Wiley \& Sons, Inc.

Panicacci, A. (2019). Do the languages migrants use in private and emotional domains define their cultural belonging more than the passport they have? International Journal of Intercultural Relations, 69, 87-101. https:// doi.org/10.1016/j.ijintrel.2019.01.003

Panicacci, A., Dewaele, J.-M. (2017). 'A Voice from Elsewhere': Acculturation, Personality and Migrants' Self-perceptions Across Languages and Cultures. International Journal of Multilingualism, 14(4), 419-436. https:// doi.org/10.1080/14790718.2016.1273937

Pollock, D. C., Van Reken, R. E., \& Pollock, M. V. (2001). Third culture kids: The experience of growing up among worlds. $2 \mathrm{~d}$ rev. ed. Nicholas Brealey.

Reference Framework of Competences for Democratic Culture (2018). Council of Europe. Strassbourg. https:/www.coe.int/en/web/ campaign-free-to-speak-safe-to-learn/-/reference-framework-of 
-competences-for-democratic-culture-volume-1-context-concepts-and-model-2018-

Resnik, P., Dewaele, J. (2020). Trait emotional intelligence, positive and negative emotions in first and foreign language classes: A mixed-methods approach. System, 94, 102-324. https://doi.org/10.1016/j.system.2020.102324

Scales, P. C. (2011). Youth developmental assets in global perspective: Results from international adaptations of the developmental assets profile. Child Indicators Research, 4(4), 619-645. https://doi.org/10.1007/s12187-011-9112-8

Sevinç, Y., Backus, A. (2017). Anxiety, language use and linguistic competence in an immigrant context: a vicious circle? International Journal of Bilingual Education and Bilingualism, 22(6), 706-724. https://doi.org/10.10 8o/13670050.2017.1306021

Sevinç, Y., Dewaele, J.-M. (2016). Heritage language anxiety and majority language anxiety among Turkish immigrants in the Netherlands. International Journal of Bilingualism, 22(2), 159-179. https:// doi.org/10.1177/0123456789123456

Shek, D. T., Dou, D., Zhu, X., \& Chai, W. (2019). Positive youth development: current perspectives. Adolescent health, medicine and therapeutics, 10, 131-141. https://doi.org/10.2147/AHMT.S179946

Strohmeier, D., Schmitt-Rodermund, E. (2008). Immigrant youth in European countries: The manifold challenges of adaptation. European Journal of Developmental Psychology, 5(2), 129-137. https://doi. org/10.1080/17405620701556953

Staring, F., Broughton, A. (2020). Education begins with language: Thematic report from a programme of seminars with peer learning to support the implementation of the Council Recommendation on a comprehensive approach to the teaching and learning of languages (2019-2020). Publications Office of the European Union. https://op.europa.eu/en/publication-detail/-/ publication/6b7e2851-b5fb-11ea-bb7a-o1aa75ed71a1/language-en

Suarez-Orozco, C., Suarez-Orozco, M. (2001). Children of immigration. Harvard University Press.

Useem, J., Useem, R. (1967). The interfaces of a binational third culture: A study of the American community in India. Journal of Social Issues, 23(1), 130143. https://doi.org/10.1111/j.1540-4560.1967.tboo567.x

van Oudenhoven, J. P., van der Zee, K. I. (2002). Predicting multicultural effectiveness of international students: The multicultural personality questionnaire. International Journal of Intercultural Relations, 26, 679-694. https://doi.org/10.1016/So1471767(o2)ooo41-X 
Wei, L., Dewaele, J., \& Housen, A. (2011). Introduction: Opportunities and challenges of bilingualism. In L. Wei, J. Dewaele \& A. Housen (Ed.), Opportunities and Challenges of Bilingualism (pp. 1-12). De Gruyter Mouton. https://doi.org/10.1515/9783110852004.1 